\title{
Experimental Organism Benign Teratoma Neoplasm
}

National Cancer Institute

\section{Source}

National Cancer Institute. Experimental Organism Benign Teratoma Neoplasm. NCI

Thesaurus. Code C114114.

A benign germ-cell neoplasm derived from pluripotent cells and consisting of components from one or more of the three germ-cell layers. 